\title{
RESISTENSI PENAMBANG ILEGAL : STUDI KASUS EKSPLOITASI TAMBANG GALIAN B (EMAS) DI DESA SAYURMATUA KECAMATAN NAGA JUANG KABUPATEN MANDAILING NATAL
}

\author{
Patmasari Nainggolan \\ Program Studi Pendidikan Geografi, \\ Fakultas Ilmu Sosial, Universitas Negeri Padang \\ Email: Patmasarinainggolan@gmail.com
}

\begin{abstract}
ABSTRAK
Penelitian ini bertujuan untuk mengetahui dan mendapatkan informasi tentang Resistensi Penambang Ilegal : Studi Kasus Eksploitasi Tambang Galian B (Emas) Di Desa Sayur Matua Kecamatan Naga Juang Kabupaten Mandailing Natal.Penelitian ini dilakukan dengan pendekatan deskriptif metode penelitian kualitatif dengan data primer dari lokasi penelitian. Penelitian ini mencoba memaparkan dan mendiskripsikan fenomena apa saja yang terjadi dalam hal resistensi penambangan ilegal : studi kasus eksploitasi tambang galian B (emas), aspek apa saja yang menyebabkan penambang emas ilegal bertahan, dan bagaimana mengetahui pemahaman masyarakat Desa Sayur Matua Kecamatan Naga Juang tentang pencemaran lingkungan sehingga penambangan ilegal masih bertahan. Hasil penelitian menemukan bahwa resistensi penambangan ilegal terdapat beberapa faktor, diantaranya yaitu : pengawasan pemerintah daerah dan peraturan daerah tentang pertambangan, Faktor sosial ekonomi ( pekerjaan, pendidikan), keinginan masyarakat untuk mengeksploitasi semaksimal mungkin; penambang hanya memperhatikan aspek keuntungan dan mengabaikan kerusakan yang ditimbulkan akibat penambangan secara terus menerus. Pemahaman masyarakat tentang dampak pertambangan bagi lingkungan, Masyarakat yang kurang memahami tentang lingkungan hanya berpikir cara untuk memenuhi kebutuhan hidup sehari-hari dengan melalui pekerjaan yang diharapkan hasilnya secara nyata.
\end{abstract}

Kata Kunci; Resistensi penambang, Eksploitasi, tambang galian B.

\begin{abstract}
This study aims to determine the resistance illegal mining: case study exploitation mine $b$ (gold) in Sayurmatua village, Naga Juang, Mandailing Natal district. This research was conducted with a qualitative research method approach with primary data from research sites, this study tries to parse and describe the phenomenon of what is happening in terms of resistance Illegal mining: a case study of the exploitation of the mine excavation B (gold), what aspects are causing illegal gold miners to survive, and how to know the understanding of the Sayurmatua village, Naga Juang Mandailing Natal distric about environmental pollution so that illegal mining still survives. The result of the study found that illegal mining resistance has several factors, such as; the supervision of local government and regional regulations on mining include, socioeconomic factors( work, education) the desire of the community to exploit it as much as possible, the miners only pay attention to the aspects of profit and ignore the damage caused by mining continuosly, the public understanding about the impact of mining for the environment, people who do not understand about the environment just think of ways to meet the needs of daily living with the expected work through the results are real.
\end{abstract}

Keywords : Resistance illegal mining, Eksploitation, mine b (gold).

\footnotetext{
${ }^{1}$ Artikel ini ditulis dari skripsi penulis dengan judul Resistensi Penambang Ilegal : Studi Kasus Eksplotasi Tambang Galian B (Emas) di Desa Sayur Matua Kecamatan Naga Juang Kabupaten Mandailing Natal
} 


\section{PENDAHULUAN}

Indonesia adalah salah satu negara yang memiliki potensi pertambangan yang sangat potensial dan melimpah, Indonesia dikenal sebagai negara yang kaya akan kandungan mineral. Secara regional Indonesia berada pada posisi tumbukan kedua lempeng besar, yaitu lempeng Pasifik dan lempeng Australia. Akibat pertemuan kedua lempeng tersebut telah menempatkan Indonesia sebagai negara yang rawan akan bencana, namun akibat adanya pergerakan lempeng tersebut menghasilkan tatanan tektonik yang lengkap, kondisi geologi tersebut mendukung kondisi pembentukan mineralisasi berbagai mineral atau bahan galian berharga lainnya.

Dari sekian banyaknya sumber daya alam yang ada di bumi ini dikelompokkan menjadi, sumber daya alam yang dapat diperbaharui dan sumber daya alam yang tidak dapat diperbaharui. Sumber daya pertambangan merupakan sumber daya yang tidak dapat diperbaharui, maka dari itu kegiatan pertambangan harus berwawasan lingkungan dan berkelanjutan.

Salah satu kabupaten yang ada di Sumatera Utara memiliki potensi pertambangan yang potensial yaitu Kabupaten Mandailing Natal. Potensi pertambangan yang ada di Mandailing Natal meliputi batubara, emas, timah hitam, perak, dan lain-lain. Sehingga Kabupaten Mandailing Natal merupakan salah satu daerah Sumatera Utara yang menjadi penghasil bahan tambang galian B (emas).
Mengingat Kabupaten Mandaiing Natal menjadi salah satu kota penyangga, tentu saja ada beberapa kegiatan pembangunan yang dilakukan di daerah ini untuk membantu mensejahterakan masyarakat. Keberadaan tambang galian B (emas) di tengah-tengah masyarakat merupakan wujud usaha masyarakat dalam mempertahankan hidupnya melalui usaha peningkatan pendapatan. Penambang dan masyarakat yang bermukim di sekitarnya merupakan dua komponen yang saling mempengaruhi.

Sebagian besar masyarakat Desa Sayurmatua berprofesi sebagai petani, akan tetapi semenjak ditemukannya penambangan emas tradisional tahun 2010 yang lalu masyarakat lebih memilih untuk menambang dibanding bertani. Penambangan emas dilakukan dengan cara menggali tanah mulai dari 35 - 100 meter di gunung Naga Juang hingga membentuk lobang yang dalam untuk memperoleh batu-batuan, kemudian batu tersebut dibawa turun dari gunung dengan cara beberapa orang digaji untuk membawa batu tersebut dan diolah di Desa Sayurmatua.

Pengolahannya dilakukan dengan cara menghaluskan batu dengan dipecah hingga batuan tersebut membentuk seperti partikel-partikel pasir, kemudian dimasukkan ke alat (galundung) untuk menghaluskan partikel tersebut yang dicampur dengan merkuri sehingga hasilnya menjadi seperti lumpur, setelah digiling kemudian lumpur tersebut dicampur dengan air raksa dan dibakar untuk memisahkan emas, perak, perunggu, pengolahan ini dilakukan oleh masyarakat Desa Sayurmatua itu 
sendiri, sehingga menimbulkan lapangan pekerjaan baru bagi masyarakat Desa Sayurmatua.

Kerusakan lingkungan karena eksploitasi emas di gunung terjadi di Desa Sayur matua, Kecamatan Naga Juang, Kabupaten Mandailing Natal. Jumlah penduduk yang terus meningkat dalam kondisi ekonomi yang lemah mengakibatkan merebaknya sebagian petani atau penambang bahan galian $\mathrm{B}$ (emas) tanpa memperhatikan konservasi lahan.

Kerusakan sumber daya alam terus mengalami peningkatan, baik dalam jumlah maupun sebaran wilayahnya. Secara fisik kerusakan tersebut disebabkan oleh tingginya eksploitasi yang dilakukan individu ataupun kelompok masyarakat itu sendiri, bukan hanya dalam kawasan produksi yang dibatasi oleh daya dukung sumber daya alam, melainkan juga terjadi di kawasan lindung dan konservasi yang telah ditetapkan sebelumnya. Gunung Naga Juang memiliki ketinggian kurang lebih 1.000 mdpl. Di gunung tersebut kita akan menemui kemah-kemah masyarakat yang melakukan kegiatan penambangan, bisa dibilang sekitar 5.000 orang ada berada di sana.

Tujuan Penelitian Berdasarkan fokus masalah di atas, maka penelitian ini bertujuan untuk mendapatkan data, mengolah, menganalisa dan membuat deskripsi tentang :

1. Untuk mengetahui aspek yang menyebabkan penambangan emas ilegal bertahan di Desa Sayurmatua Kecamatan Naga
Juang Kabupaten Mandailing

Natal.

2. Untuk mengetahui pemahaman masyarakat Desa Sayurmatua Kecamatan Naga Juang Kabupaten Mandailing Natal tentang pencemaran lingkungan sehingga penambangan ilegal masih bertahan.

Menurut kamus besar bahasa Indonesia resistensi merupakan tindakan bertahan. Resistensi (Inggris: resistance) berasal dari kata resis dan ance, adalah menunjukkan pada posisi sebuah sikap untuk berprilaku bertahan, berusaha melawan, menentang atau upaya oposisi pada umumnya sikap ini tidak berdasarkan atau perujuk pada paham yang jelas. (Http/id.wikipedia.org/wiki/resistensi).

Resistensi dapat dilihat sebagai materialisasi atau perwujudan yang paling aktual dari hasrat untuk menolak dominasi pengetahuan atau kekuasaan. Menurut Scott definisi resistensi adalah setiap semua tindakan para anggota kelas masyarakat yang rendah dengan maksud melunakkan atau menolak tuntutan tuntutan (misalnya sewa, pajak) yang dikenakan pada kelas itu oleh kelas-kelas yang lebih atas (misalnya tuan tanah, negara, pemilik mesin, pemberi pinjaman uang) atau untuk mengajukan tuntutan-tuntutannya sendiri (misalnya pekerjaan, lahan, kemurahan hati, penghargaan) terhadap kelas-kelas atasan ini. Bentuk resistensi sangat beragam dan dapat dilihat adalah suatu bentuk ketidakpatuhan, penolakan terhadap kondisi yang mereka tidak sukai. Berbagai upaya mereka lakukan 
untuk tetap bertahan dan mencari penghidupan yang layak.

Pertambangan adalah suatu kegiatan pengambilan endapan galian berharga dan bernilai ekonomis dari dalam kulit bumi, baik secara mekanis maupun manual, pada permukaan bumi maupun dibawah permukaan bumi. Hasil kegiatan pertambangan antara lain, minyak dan gas bumi, biji mangan, biji emas, batu bara, pasir, biji besi, timah nikel, biji bauksit, tembaga, granit dan lain-lain.

Ahyani (2011) menjelaskan bahwa persebaran barang tambang di Indonesia tidak merata secara keseluruhan. Setiap daerah memiliki potensi masing-masing sesuai dengan kondisi alamnya. Tidak semua daerah memiliki sumber barang tambang yang sama. Keadaan ini disebabkan oleh dua faktor sebagai berikut:

1) Sejarah geologi masing-masing wilayah berbeda.

Masing-masing wilayah memiliki sejarah geologi yang berbeda, ini dapat ditunjukkan dengan kondisi alam disekitarnya. Yang paling mudah dijumpai ialah keadaan batuan dan kenampakan geomorfologi yang membentang di wilayah tersebut. Kenampakan seperti gunung berapi dan segala material yang pernah terhempas keluar akibat aliran lava. Selain itu adanya pegunungan lipatan akibat proses konvergensi maupun divergensi antar lempeng, kenampakan lainnya seperti bekas pengangkatan dasar laut hingga diatas permukaan air laut yang membentuk formasi karst. Dengan perbedaan tersebut maka mineralmineral maupun energi yang terkandung di dalam perut bumi juga akan berbeda.

2) Belum adanya penelitian yang mendalam mengenai potensi-potensi tambang di suatu wilayah melalui penyelidikan geologi dan sumber daya mineral.

Pertambangan dapat menciptakan kerusakan lingkungan yang serius dalam suatu kawasan atau wilayah. Potensi kerusakan tergantung dari berbagai faktor kegiatan pertambangan antara lain pada teknik pertambangan, pengolahan dan lain sebagainya. Sedangkan faktor lingkungan antara lain faktor geografis dan morfologis, fauna dan flora, hidrologis dan lain-lain.

Undang-undang

Pokok

Pertambangan Republik Indonesia No 11 Tahun 1967 pasal 3, yang menyebutkan penggolongan bahan galian sebagai berikut :

a. Bahan galian golongan A, merupakan (bahan galian strategis), adalah bahan galian yang mempunyai peranan penting untuk kelangsungan kehidupan negara misalnya : minyak bumi, gas alam, batu bara, timah putih, besi, nikel, bahan galian jenis ini di kuasai oleh negara.

b. Bahan galian golongan B, merupakan (bahan galian Vital), adalah bahan galian yang mempunyai peranan penting untuk kelangsungan kegiatan perekonomian negara dan dikuasai oleh negara dengan menyertakan rakyat, misalnya : emas, perak, intan, timah hitam, belerang, air raksa, bahan galian ini dapat diusahakan 
oleh badan usaha milik negara ataupun bersama-sama dengan rakyat.

c. Bahan galian golongan C, (bukan merupakan bahan galian strategis ataupun Vital), karena sifatnya tidak langsung memerlukan pasaran yang bersifat internasional. Contohnya marmer, batu kapur, tanah liat, pasir, yang sepanjang tidak mengandung unsur mineral.

Yang kemudian diperbaharui dengan keberadaan Undang-Undang Nomor 4 Tahun 2009 tentang pertambangan mineral dan batubara. Kedua Undang-Undang tersebut samasama mengatur tentang pengolahan bahan galian dan sistem pengolahannya. Penggolongan bahan galian dalam UU No.4 Tahun 2009 diatur berdasarkan pada kelompok usaha pertambangan yaitu pertambangan mineral dan pertambangan batubara. Pertambangan mineral digolongkan menjadi empat jenis yaitu pertambangan mineral radioaktif, mineral logam, mineral bukan logam, dan pertambangan batuan.

Eksploitasi adalah usaha penambangan dengan maksud untuk menghasilkan bahan galian dan memanfaatkannya. Kegiatan ini dapat dibedakan berdasarkan sifat bahan galiannya yaitu, galian padat dan bahan galian cair serta gas. Eksploitasi merupakan pengambilan sumberdaya alam untuk dipakai atau dipergunakan atau dimanfaatkan dalam berbagai keperluan manusia dalam memenuhi kebutuhannya.

Defenisi sumber daya alam Undang-Undang Republik Indonesia Nomor 32 Tahun 2009 Tentang
Perlindungan Dan Pengelolaan Lingkungan Hidup;

"Sumber daya alam adalah unsur lingkungan hidup yang terdiri atas sumber daya hayati dan non hayati yang secara keseluruhan membentuk kesatuan ekosistem".

Klasifikasi sumber daya alam berdasarkan jenisnya yaitu : Sumber daya alam hayati (biotik) berasal dari makhluk hidup dan Sumber daya alam non hayati (abiotik) berasal dari benda tak hidup seperti bahan tambang. Klasifikasi sumber daya alam berdasarkan sifatnya yaitu: a. sumber daya alam yang dapat diperbaharui (renewable resource) dapat digunakan berulang atau dilestarikan ,contoh sumber daya alam hayati. b. sumber daya alam yang tidak dapat diperbaharui (non renewable resources) tidak dapat didaur ulang, digunakan sekali saja / tidak dapat dilestarikan, contoh : minyak bumi, batu bara, dan gas alam. c. tidak terbatas jumlahnya ( unlimited) seperti : sinar matahari, udara, arus laut. Klasifikasi sumber daya alam berdasarkan penggunaanya , a. sumber daya alam penghasil bahan baku, dapat digunakan untuk menghasilkan benda/barang lain sehingga bernilai tinggi, contoh : hasil hutan, barang tambang. b. sumber daya alam penghasil energi, yang dapat menghasilkan energi, contoh sinar matahari, minyak bumi, dan sebagainya.

Kerusakan alam dimulai secara aktif bersamaan dengan revolusi industri sekitar dua abad yang lalu. Berbagai macam barang diproduksi untuk memenuhi kebutuhan hidup manusia. Dengan ditemukannya mesin uap dan mesin motor bakar, lebih 
mempercepat pertumbuhan aneka industri untuk perbaikan kesejahteraan hidup umat manusia. Peningkatan kesejahteraan hidup juga mempercepat pertumbuhan jumlah penduduk yang membutuhkan segala sarana dan prasarananya terutama untuk memenuhi segala kebutuhan disektor pangan (Iswandi, 2012 : 110).

\section{Pada dasarnya, masalah} lingkungan hidup dapat dikelompokkan ke dalam dua bentuk, yaitu pencemaran lingkungan (environmental pollution) dan terkurasnya sumber daya (resources depletion). Dalam undang-undang No.23 Tahun 1997 tentang pengelolaan lingkungan hidup, pasal 1 ayat 12 dinyatakan bahwa;

Pencemaran lingkungan adalah masuknya atau dimasukkannya makhluk hidup, zat, energi dan atau komponen lain ke dalam lingkungan hidup oleh kegiatan, sehingga kualitasnya hidup tak berfungsi lagi sesuai peruntukannya.

Suatu zat dinamakan sebagai zat pencemar atau polutan apabila kadarnya melebihi batas normal, berada pada tempat yang tidak semestinya dan berada pada waktu yang tidak tepat. Menurut wujudnya, zat pencemar dapat dibagi dalam 3 kategori, yaitu zat pencemar padat, cair dan gas, sedangkan menurut sifat kimianya zat pencemar dapat dibagi kedalam 2 kategori, yaitu zat pencemar organik dan zat pencemar anorganik, dan menurut faktor-faktor yang dicemarinya pencemaran dapat dibagi menjadi yaitu, pencemaran udara, pencemaran air, pencemaran tanah dan pencemaran suara (Iswandi, 2012 :112).

$$
\text { Dalam Undang-Undang }
$$

Republik Indonesia Nomor 20/1990 tentang Pengendalian Pencemaran Air, pencemaran air didefinisikan sebagai :

“ Pencemaran air adalah masuknya atau dimasukkannya mahluk hidup, zat, energi dan atau komponen lain ke dalam air oleh kegiatan manusia sehingga kualitas air turun sampai ketingkat tertentu yang menyebabkan air tidak berfungsi lagi sesuai dengan peruntukannya" (Pasal 1, angka 2).

Air adalah dasar untuk lingkungan yang subur dan mendukung sebagian besar kegiatan manusia, antara lain: pertanian, industri, dan rumah tangga (Dedi Hermon,2010 : 62).

$$
\text { Amos Neolaka (2007:41) , }
$$
menjelaskan bahwa faktor yang mempengaruhi kesadaran Lingkungan ;

a. Faktor Ketidaktahuan

b. Manusia Indonesia belum memiliki pengetahuan yang benar tentang ligkungan hidup. Oleh karena belum memiliki pengetahuan tentang lingkungan hidup maka jelas akan mempengaruhi kesadaran lingkungan.

c. Faktor Kemiskinan

Masalah lingkungan hidup timbul akibat ketidakseimbangan antara jumlah penduduk yang besar dengan sumber daya alam yang semakin berkurang.

d. Faktor Kemanusiaan

Manusia adalah sejenis makhluk hidup, karena itu manusia juga berinteraksi dengan lingkungannya.

e. Faktor Gaya Hidup 
Gaya hidup yang dapat meningkatnya kerusakan lingkungan hidup yaitu; gaya hidup menekankan kenikmatan, gaya hidup yang mementingkan materi, gaya hidup konsumtif, gaya hidup sekuler, gaya hidup yang mementingkan diri sendiri.

\section{METODE PENELITIAN}

\section{Jenis Penelitian}

Penelitian ini menggunakan metode Kualitatif dengan pendekatan deskriptif yang bermaksud untuk memberikan gambaran umum tentang lokasi penelitian yaitu Eksploitasi tambang galian B (emas). Jenis penelitian ini adalah penelitian kualitatif deskriptif, yaitu data yang dikumpulkan berbentuk kata-kata, gambar, bukan angka-angka. Menurut Bogdan dan Taylor, sebagaimana yang dikutip oleh Lexy J. Moleong (2012:4), penelitian kualitatif adalah prosedur penelitian yang menghasilkan data deskriptif berupa kata-kata tertulis atau lisan dari orang-orang dan perilaku yang diamati.

\section{Instrumen Penelitian}

Informan (subjek penelitian) dalam penelitian ini akan dipilih secara Snowball Sampling yaitu teknik pengumpulan sampel yang mula-mula jumlahnya kecil, kemudian membesar. Berangkat dari judul penelitian ini mengenai resistensi penambang ilegal : studi kasus Eksploitasi tambang galian B (emas) di Desa Sayur Matua Kabupaten Mandaailing Natal, maka pemilihan informan terdiri dari berbagai kalangan yang berasal dari Desa Sayur Matua, yaitu dari pihak dari Pemerintah setempat, masyarakat, para pemilik pertambangan emas, buruh dan tokoh masyarakat.

\section{Teknik Pengumpulan Data}

Teknik pengumpulan data adalah cara yang dilakukan peneliti untuk mengumpulkan data yang dibutuhkan sesuai dengan fokus penelitiannya. Teknik pengumpulan data harus disesuaikan dengan metode penelitian dan fokus penelitian, sehingga mempermudah peneliti untuk memperoleh data yang valid. Catherin Marshall mengatakan dalam Sugiyono (2011:308) Dalam penelitian kualitatif, pengumpulan data dilakukan pada natural setting (kondisi yang alamiah), sumber data primer, dan teknik pengumpulan data lebih banyak pada observasi berperanserta ( participan observation), wawancara mendalam ( in depth interview) dan dokumentasi.

\section{Teknik Analisa Data}

Analisa data pada penelitian kualitatif dimulai dari pengumpulan data sampai kepada penarikan kesimpulan penelitian. Oleh karena itu peneliti merupakan instrumen utama dalam penelitian. Data yang telah dikumpulkan setiap hari selama penelitian akan dibuatkan laporan lapangan, untuk mengungkapkan data apa yang masih perlu dicari, pertanyaan apa yang belum dijawab, metode apa yang harus digunakan untuk mendapatkan informasi baru, dan kesalahan apa yang perlu diperbaiki, serta data yang mana yang tidak diperlukan.

\section{Reduksi Data}

Data yang diperoleh dilapangan langsung diketik dengan rapi, terinci 
secara sistematis setiap selesai mengumpulkan data.Laporan lapangan direduksi, yaitu dengan memilih hal-hal pokok yang sesuai dengan masalah penelitian, selanjutnya diberi tema dan kode pada aspek tertentu.

\section{Pengambilan Kesimpulan}

Mengambil

kesimpulan

merupakan analisi lanjutan dari reduksi data, dan display data sehingga data dapat disimpulkan, dan peneliti masih berpeluang untuk menerima masukan. Penarikan kesimpulan sementara, masih dapat diuji kembali dengan data di lapangan, dengan cara merefleksi kembali, peneliti dapat bertukar fikiran dengan teman sejawat, triangulasi, sehingga kebenaran ilmiah dapat tercapai. Setelah hasil penelitian telah diuji kebenarannya, maka peneliti dapat menarik kesimpulan dalam bentuk deskriptif sebagai laporan penelitian.

\section{Pengabsahan Data}

Dalam penelitian kualitatif, pengabsahan data merupakan salah satu faktor yang sangat penting, karena tanpa pengabsahan data yang diperoleh dari lapangan maka akan sulit seorang peneliti untuk mempertanggungjawabkan hasil penelitiannya. Untuk melihat derajat kebenaran dari hasil penelitian ini, maka dilakukan pemeriksaan data, hal ini didasarkan pada pandangan Moleong (2012;173) yang mengisyaratkan bahwa "untuk menetapkan keabsahan data diperlukan pemeriksaan data". Pengabsahan data dalam penelitian ini, maka akan dilakukan dengan melalui cara; (1) mendiskusikan dengan temanteman mahasiswa S1 khususnya mahasiswa geografi baik secara formal maupun nonformal atau mendiskusikan dengan para Dosen Geografi FIS UNP, (2) dilakukan triangulasi dengan melakukan cross check dengan sumber data yakni membandingkan data hasil pengamatan dengan hasil wawancara, (3) dilakukan pengamatan secara tekun, (4) dilakukan pengecekan terhadap temuan dilapangan. Selain itu mengecek apakah hasil penelitian ini benar atau salah sesuai dengan metodologi yang digunakan, dan peneliti selalu mendiskusikan dengan dosen pembimbing.

\section{HASIL PENELITIAN DAN PEMBAHASAN}

\section{Beberapa Penyebab Penambangan Emas Ilegal Bertahan di Desa Sayur Matua Kecamatan Naga Juang Kabupaten Mandailing Natal}

a. Pengawasan Pemerintah Daerah dan Peraturan Daerah Tentang Pertambangan

Resistensi penambangan ilegal yang terjadi di Desa Sayur Matua merupakan dampak dari keinginan untuk mempertahankan diri mereka. Keinginan tersebut pada awalnya hanya didasari oleh keinginan untuk mencari tambahan penghasilan untuk penghidupan, karena melihat orang lain yang dianggap menguntungkan dalan profesi tersebut, keinginan untuk mendapatkan upah yang lebih besar, keinginan untuk meperoleh profesi yang lebih baik. Hal ini yang kemudian yang menjadi sebahagian alasan bertahannya para penambang di Desa Sayur Matua.

Keberadaan penambangan emas di Desa Sayur Matua Kecamatan Naga Juang Kabupaten Mandailing Natal 
telah menjadikan daerah tersebut sebagai salah satu penghasil emas yang ada di Kabupaten Mandailing Natal, dan penambang mempekerjakan masyarakat di Desa Sayur Matua untuk tambahan biaya hidup sehari-hari. Dimana penambang memerlukan masyarakat sekitar dalam proses pekerjaan penambangan, oleh karena itu aktivitas penambang memiliki dampak negative terhadap masyarakat di sekitar areal pertambangan.

b. Pengetahuan dan Pemahaman Masyarakat Tentang Aspek Legal Untuk melakukan usaha pertambangan, inilah yang dimaksud dengan pertambangan rakyat. Kewenangan memberi izin pertambangan rakyat ini merupakan kewenangan pemerintah daerah. Dalam pasal 67 Undang-undang Nomor 4 Tahun 2009 disebutkan sebagai berikut :

(1) Bupati / walikota memberikan Izin Pertamabangan Rakyat terutama kepada penduduk setempat, baik perseorangan maupun kelompok masyarakat dan/atau koperasi.

(2) Bupati/walikota dapat melimpahkan kewenangan pelaksanaan pemberian Izin Pertambangan Rakyat sebagaimana dimaksud pada ayat (1) kepada camat sesuai dengan ketentuan peraturan perundang-undangan.

(3) Untuk memperoleh Izin Pertambangan Rakyat sebagaimana dimaksud pada ayat (1) pemohon wajib menyampaikan kepada bupati/walikota.

c. Ketidaktegasan pemerintah dalam penegakan kebijakan

Penegakan peraturan dimaksudkan sebagai bentuk ketegasan pemerintah dalam menertibkan aktivitas penambangan emas tradisional tersebut, Seperti paparan informan tersebut diatas, sampai saat ini pertambangan tradisional yang ada di Naga Juang masih belum resmi ataupun ilegal, dalam menegakkan Perda tersebut, dibutuhkan bantuan dari banyak pihak, terutama masyarakat. Pemerintah sebagai pembuat kebijakan dan masyarakat sebagai sasaran dari kebijakan tersebut. Setiap masyarakat memiliki hak yang sama terhadap pengelolaan sumber daya alam terutama bagi masyarakat yang berada di sekitar sumber daya alam tersebut. Struktur inilah yang menyebabkan prilaku individualisme muncul kepermukaan.

d. Penyuluhan dan Sosialisasi

Penambang sama sekali tidak mengetahui tentang pasal-pasal yang mengatur tentang aktivitas penambangan. Hal yang lebih memprihatinkan lagi, masyarakat sekitar yang menjadi bagian dari sasaran perda tersebut juga tidak mengetahui tentang Perda tersebut. Petugas Dinas Pertambangan Sumber Daya Mineral sebagai salah satu pihak yang bertanggungjawab terhadap Perda tersebut bahkan tidak pernah melakukan sosialisasi kepada masyarakat terkait aktivitas 
penambangan yang dilakukan oleh masyarakat yang dianggap masyarakat sebagai tambang rakyat.

e. Faktor Sosial Ekonomi

1. Pekerjaan

Bekerja sebagai penambang emas bisa sebagai buruh bias juga sebagai pemberi modal. Kegiatan penambangan emas menjadi daya tarik, sehingga penduduk banyak yang ikutserta dalam kegiatan tersebut. Pekerjaan baru yang terbentuk dengan adanya penambangan tersebut antara lain buruh dan penambang. Buruh tambang menurut kamus besar Bahasa Indonesia adalah orang yang bekerja untuk orang lain dengan mendapat upah, sedangkan penambang merupakan orang yang bekerja dengan mengandalkan kekuatan fisiknya (seperti membongkar muatan kapal, mengangkut barang dari satu tempat ke tempat yang lain).

Begitu juga dengan masyarakat yang dahulunya menjadi buruh tani, upah masyarakat lebih besar dengan menjadi buruh tambang. Kegiatan penambangan emas secara nyata meningkatkan penghasilan dari sebagian masyarakat. Kaum perempuan yang berjualan makanan keliling di lokasi penambangan juga meningkat penghasilannya.

2. Pendidikan

Di Desa Sayur Matua sendiri, tingkat pendidikan masyarakat tersebut masih bervariasi, di Desa Sayur Matua sendiri terdapat lulusan berbagai tingkat pendidikan, yaitu lulusan SD bahkan ada yang tidak sempat lulus di bangku SD, lulusan SLTP, lulusan SLTA dan lulusan perguruan tinggi tidak terlalu banyak. Pada umumnya masyarakat Desa Sayur Matua mendominasi lulusan tingkat SLTA.

f. Keinginan Mengeksploitasi Semaksimal Mungkin

Sampai sejauh ini informan masih merasakan keuntungan, dan informan akan tetap bertahan sebagai penambang apabila pekerjaan itu masih memberinya keuntungan terus menerus, karena sebelumnya informan hanya sebagai petani karet, dan informan menjelaskan aktivitas penambangan ini seperti main judi kalau keberuntungan memihak kekayaan akan selalu menghampiri. Tujuan pengolahan sumber daya alam dan energi untuk mencapai tingkat penggunaan yang optimal tergantung pada tingkat pemanfaatan. Pemanfaatan yang berlebihan dan lebih besar dari eksploitasi akan mempercepat habisnya sumber daya alam dan energi.

\section{Pemahaman masyarakat tentang dampak pertambangan bagi lingkungan}

Masyarakat kurang memahami akibat jangka panjang yang disebabkan oleh penambangan emas yang dilakukan terus-menerus. Pemilik tambang hanya memperhatikan aspek keuntungan dan mengabaikan kerusakan yang ditimbulkan. Masyarakat yang kurang memahami tentang lingkungan hanya berpikir cara untuk memenuhi 
kebutuhan hidup sehari-hari dengan melalui pekerjaan yang dapat diharapkan hasilnya secara nyata. Keberlanjutan dari usaha yang dilakukan dalam jangka panjang tidak dipikirkan. Beberapa orang buruh tidak mengetahui tentang lingkungan hidup, yang ada dalam pikiran hanya cara-cara untuk mendapatkan uang agar dapat hidup layak.

\section{PENUTUP}

\section{Kesimpulan}

1. Beberapa penyebab penambangan emas ilegal bertahan di desa sayur matua kecamatan naga juang kabupaten mandailing natal yaitu : pengawasan pemerintah daerah dan peraturan daerah tentang pertambangan meliputi

pengetahuan dan pemahaman masyarakat tentang aspek legal, ketidaktegasan pemerintah dalam penegakan kebijakan, penyuluhan dan sosialisasi bisa dikatakan hanya sekali dua kali saja sehingga para penambang ilegal tidak mengetahui status pekerjaaan penambang tersebut), Faktor sosial ekonomi ,keinginan masyarakat untuk mengeksploitasi semaksimal mungkin; penambang hanya memperhatikan aspek keuntungan dan mengabaikan kerusakan yang ditimbulkan akibat penambangan secara terus menerus.

2. Pemahaman masyarakat tentang dampak pertambangan bagi lingkungan

Masyarakat yang kurang memahami tentang lingkungan hanya berpikir cara untuk memenuhi kebutuhan hidup sehari-hari dengan melalui pekerjaan yang dapat diharapkan hasilnya secara nyata. Keberlanjutan dari usaha yang dilakukan dalam jangka panjang tidak dipikirkan.

\section{Saran}

Berdasarkan kesimpulan hasil penelitian, maka peneliti memberikan beberapa saran yang dapat diberikan kepada pembaca yaitu:

1. Pemanfaatan tambang galian harus memperhatikan dampak lingkungan. Keberadaan penambangan memberikan dampak fisik dan dampak sosial ekonomi baik positif maupun negatif, maka diperlukan suatu upaya pengelolaan lingkungan agar dampak negatif yang terjadi tidak meluas.

2. Pemerintah perlu melakukan sosialisasi terkait peraturan daerah yang telah ada agar masyarakat bisa memahami kebijakan yang dibuat tersebut.

3. Alam memberikan semua apa yang kita butuhkan tapi kita harus berpikir keseimbangan tersebut sampai kepada anak cucu kita, apabila mengeksploitasi secara besar-besaran dan mendapatkan keuntungan besar, setelahnya " kita tidak bisa mendapatkan oksigen dan makan dengan uang melainkan tergantung kepada alam".

4. Setelah adanya penelitian ini, diharapkan tidak akan berhenti sampai disini saja, perlu adanya pengembangan untuk meneliti lebih lanjut dimasa yang akan mendatang. 
DAFTAR PUSTAKA

Anonim,

(http://adamfa119.blogspot.co.id/20

15/03/Pengertian-Dan-Jenis

Pertambangan.html). Diakses 2209-2016 pukul 11.30 WIB.

Burhan, Bugin. 2008. Analisis Data Penelitian Kualitatif. Jakarta: Rajawali Pers.

Faisal, Sanafiah. 1990. Penelitian Kualitatif Dasar-Dasar Dan Aplikasi. Jakarta: Raja Grafindo Persada.

Http/id.wikipedia.org/wiki/resistensi.

Diakses 22-09-2016 pukul 12.27 WIB.

Hermon, Dedi. 2010. Geografi Lingkungan. Padang: UNP Press.

Iswandi U. 2012. Ekologi Dan Ilmu Lingkungan. Padang: UNP Press.

Departemen Pendidikan Nasional,2011. Kamus Besar Bahasa Indonesia.Jakarta: Balai Pustaka.

Kurniawan,A.Hamzah. 2013. Persistensi Dan Resistensi Masyarakat Terhadap Eksistensi Pertambangan Emas Di Desa Bonto Katute Kabupaten Sinjai.Makassar : FIS Universitas Hasanuddin.

Lexy J.Moelong. 2012. Metodologi Penelitian Kualitatif. Bandung:PT.Remaja Rosdakrya.
M.Nur. 2014. Resistensi Penambang Rakyat : Studi Kasus Eksploitasi Tambang Galian C (Pasir) Di Desa Borimasunggu Kabupaten Maros.Skripsi Fakultas Ilmu Sosial Dan Ilmu Politik Universitas Hasanuddin.

Mochammad.Ahyani. 2011. Pengaruh Kegiatan Penambangan Emas Terhadap Kondisi Kerusakan Tanah Pada Wilayah Pertambangan Rakyat Di Bombana Provinsi Sulawesi Tenggara. Tesis Program Magister Lingkungan Universitas Diponegoro.

Neolaka, Amos. 2007. Kesadaran Lingkungan. Jakarta.PT : Rineka Cipta. Sugiyono.2011. Metode Penelitian Kualitatif, Kuantitatif Dan (Mixed Methods). Bandung: CV.ALFABETA.

Pasaribu, Arman. 2010. Analisis Dampak Pertambangan Emas Terhadap Sosial Ekonomi Masyarakat Di Kecamatan Batang Toru Kabupaten Tapanuli Selatan. Medan :Sekolah Pascasarjana USU. 